\title{
THE CULTURE OF THE NOBILITY OF KYIV PROVINCE IN THE FIRST HALF OF THE $19^{\mathrm{TH}}$ CENTURY
}

\author{
Liubomyr Hubytskyi \\ $\mathrm{PhD}$, Associate Professor at the Department of Philosophy, Sociology and Political Science, \\ Kyiv National University of Trade and Economics, Ukraine \\ e-mail: 1.gubytskyi@knute.edu.ua,orcid.org/0000-0002-8511-6461

\section{Vitalii Razitskyi} \\ $\mathrm{PhD}$, Associate Professor at the Department of Philosophy, Sociology and Political Science, \\ Kyiv National University of Trade and Economics, Ukraine \\ e-mail: v.razitskyy@knute.edu.ua,orcid.org/0000-0002-1048-3419

\section{Iryna Kyzymenko} \\ PhD, Associate Professor at the Department of Philosophy, Sociology and Political Science, \\ Kyiv National University of Trade and Economics, Ukraine \\ e-mail: i.kyzymenko@knute.edu.ua,orcid.org/0000-0002-2148-9488
}

\section{Olena Krasilnikova}

$\mathrm{PhD}$, Associate Professor at the Department of Philosophy, Sociology and Political Science,

Kyiv National University of Trade and Economics, Ukraine

e-mail: o.krasilnikova@knute.edu.ua, orcid.org/0000-0003-3346-756

\section{Jan Holonic}

Professor, Ph.D., Polonia University in Czestochowa, Interdisciplinary Faculty, Poland

e-mail: jholonic@ap.edu.pl,orcid.org/0000-0003-2165-0275

\section{Summary}

The authors made an attempt to explore the particularities of the economic development and the financial standing of the Nobility of Kyiv Province in the First Half of the 19th Century. The Ukrainian nobility originates from the senior Cossack officers (starshyna) and the RightBank gentry (shliakhta), who received privileges and began to serve to the czarist government of the Russian Empire. The noblemen had to meet the requirements of their privileged position, including their activity in every sphere: economic, financial, credit, educational. The attitude of the imperial authorities towards the gentry depended on their loyalty; in case of such loyalty, the gentry were granted legal supremacy and financial benefits, even under conditions of persistent state budget deficits. A favorable attitude to the idleness and eternal leisure contributed to deepening crisis in nurturing palette of high aristocratic feelings. In this context, particular attention was paid to the significant influence of the legal and economic advantages of the Kyiv Province nobility on further development of this privileged social stratum.

Keywords: nobility, landlords, dancing ball (party), Cossack, privileged society strata.

\section{DOI https://doi.org/10.23856/3907}

\section{Introduction}

The current processes of formation and self-realization of the Ukrainian elite require a detailed explanation. The relevance of this study is prompted by the fact that the modern Ukrainian elite is going through the same "growing pains" that were inherent in the $19^{\text {th }}$ century processes. The aim of the article is to identify and interpret the economic and financial 
conditions for the rise of the Ukrainian component of the Russian nobility co-opted from the senior Cossack officers and the Right-Bank gentry as well as to define the attitude of the imperial authorities towards the Ukrainian nobility.

The questions of the noble culture were investigated by A. Romanovych-Slavatynskyi (A. Romanovich-Slavatinskii, 1870), F. Ernst (Fedir Ernst, 1997), A. Kolesnykova (Anna Kolesnykova, 2005), I. Rozental (Isaak Rozental, 2007) and other scientists.

The complexities of the social vicissitudes of the $18^{\text {th }}-19^{\text {th }}$ centuries were analyzed in the works of N. Yakovenko (N. Yakovenko, 2005) and P. Vandych (P. Vandych, 2004). The results of the process of feudalizing the senior Cossack officers and enslaving Ukrainian society were examined in the works of I. Hurzhiy (I. Hurzhii, 1954), O. Hurzhiy and V.Orlyk (V.Orlyk, 2012). The processes of "elevation" and "ennoblement" became dominant among the Cossack elites in the Right- and LeftBank Ukraine, Slobidska (Sloboda) Ukraine and Zaporizhzhia. Similar social processes took place on both sides of the Dnieper River - the petty gentry of the Right Bank sought livelihood by serving the magnates, while the Left-Bank Ukraine witnessed the process of the ennoblement of the Cossack starshyna (S. Lysenko, Ye. Chernetskyi, 2006). Yet the choice of the senior Cossack officers co-opted into both the Polish and Russian communities proved wrong since it led to the destruction of principles of the civil society built on the foundation of the blood they shed together in battles against the enemies (P. Stepa, 2010). The process of incorporating the newly established "Little Russian" nobility of the Russian state's Ukrainian provinces into the model of relations that dominated in the empire was analyzed in the works of Z. Kohut (Z.Kohut, 1996) and Ya. Hrytsak (Ya.Hrytsak, 2000).

The Russian feudalism of the $18^{\text {th }}-19^{\text {th }}$ centuries, constantly undermined by the growing influence of foreign and domestic moneylenders, despite its external military might, was gradually turning into "the sick man of Europe" since it led to the social differentiation in Russian and subservient Ukrainian societies, including the newly emergent Ukrainian nobility. These aspects were detailed in the works of S. Borovoi (S. Borovoi, 1958), N. Mordvinov (N. Mordvinov, 1829), V. Smelkov (V. Smelkov, 1904), Ye. Lavrentieva (Ye. Lavrentieva, 2007) and others. The Russian Empire's active and aggressive foreign policy brought about the fast territorial gains. Nevertheless, even the wealth of the conquered territories was not enough to satisfy the thirst of the Russian royal court for luxury or the army's hunger for further conquests. Russia's external and internal debt was growing, a phenomenon, which was researched in the works of M. Bogolepov (M. Bogolepov, 1910), I. Gindin (I. Gindin, 1960), P. Migulin (P. Migulin, 1904), P. Khromov (P. Khromov, 1950) and others.

\section{The social status of the Ukrainian nobility in Kyiv Province of the Russian Empire}

The bureaucratic machine of the imperial Russia possessed a truly unlimited power. It did not pay much attention to the moral criteria of good and evil and tried to regulate all aspects of the society's life. This "invisible" machine produced and reproduced a special type of personality, without which it could not function effectively. The model of such a personality was characterizes by the ordinariness, obedience, conformism, mediocrity as well as by not accepting critical attitude to the surrounding reality, intellectual and moral courage and admiration for creative activity. As for the career of an official, there were the following informal traditions: to get a better chance to move forward on the ladder of the service hierarchy and receive the favors of the higher echelons officials a person should less manifest human essence and critically think, feel cowardice and show mediocrity. (V. Polikarpov, 1995:162) Of course, in such a peculiar society, it did not matter what social stratum we would consider - nobility, clergy, merchants, etc., even manners of behavior were painted in serf-slave tones. (V. Polikarpov, 1995:169) 
The youngest philosopher of the "learned wife" of Peter the Great - Antioch Cantemir gave an analysis of human manners in his satires: "Na zavist i hordost dvorian zlonravnyh" ("To the envy and pride of the evil nobles"), "O razlichii strastei chelovecheskih" ("About the difference of human passions"), "K umu svoiemu" ("To the mind of mine") etc. He derived this position from the idea of the equality of people by their nature: "... in free people as well (as in slaves are the same flesh and bones and the same blood flows)" (V. Polikarpov, 1995:170). Not a nobility ("noble origin") gives a person a sense of dignity and respect among the society, but good manners and also an honest attitude towards your cause.

"Noble" and "sneaky" man, according to A. Cantemir, is not such from birth - it depends on the availability of the "noble" and "sneaky" soul. (V. Polikarpov, 1995:170)

At the turn of the XVIII ${ }^{\text {th }}$ and XIX ${ }^{\text {th }}$ centuries, many Russian enlighteners and intellectuals felt aversion to the tyranny of the landlords, the "sensitivity to the peasant class" and rejected such manners as social strata's arrogance, rudeness, cruelty and so on... (V. Polikarpov, 1995:176)

The manners of behavior of Orthodox clergies can be understood only in the context of the Russian culture and everyday life with its deep specific religiosity. (V. Polikarpov, 1995:213) During the "golden age", prior to the metric books introduction, priests could marry whomever they wanted for money or a bucket of vodka, and therefore there was a commonplace affair of duality and trinity in a marriage. (V. Polikarpov, 1995:224)

Nevertheless, a number of manners, inherent in the seventeenth and eighteenth centuries, survived and continued their existence in the nineteenth and early twentieth centuries: alcoholism, apostasy, gluttony, dishonesty etc. (V. Polikarpov, 1995:225)

The state formed a pattern of behavior that led to spending vast resources by a small elite group and strongly supported it even in the face of bankruptcy.

The question to achieve harmony in the state-landowner relationship was maintained at an appropriate level. A nobleman had to meet the requirements of his privileged position, which would induce activity in every sphere: economic, financial, credit, educational etc. The state did not tolerate financial indebtedness of the taxable social classes but it adopted a different position to the nobility.

Thus, the creditors of a landowner named Zakhariy Holovynskiy included more than five hundred nobles who in 1831 claimed "the estate of the plaintiff in Bohuslav District, which comprised the villages of Prytsek, Burt, Makedon, Pyvets and Onatsok with 1,805 serfs according to the latest audit and more than a million rubles of official debt" (The Central State Historical Archives of Ukraine in Kyiv (CSHAK), Fund 486, description 9, file 2, 495p.). From 1824 onward the State Bank, that gave Holovynskiy a 448,000 rubles loan with an $8 \%$ annual interest rate for a period of 24 years, was also one of his creditors (The Central State Historical Archives of Ukraine in Kyiv (CSHAK), Fund 491, description 45, file 14, 25p).

In the governorate cities there were located restaurants, taverns, hotels, guest houses for nobles' usage. Sometimes the owners of the restaurants were foreigners, as in the case of the Litinskii restaurant. In January 1846, the temporary executor of duties of the governor of the city of Khamianets and civilian governor of Podolia district, Major General Radyshchev appealed to the Kyiv Governor-General with a request to allow "an Austrian citizen, Michalina Klimbergova, to own a restaurant in Litin town for the payment, that she had offered before (11 rubles and 45 coins in silver per year)" (The Central State Historical Archives of Ukraine in Kyiv (CSHAK) (Fund 442, description 79, file 19, p.1).

It is worth to note, that the landlords and their families in the exile also lived in decent conditions. For example, a dekabrist S.H. Volkonskyi's wife Maria remembered the Siberian exile in Irkutsk: "Our means were not so limited, as in the casemate. I received ten thousand rubles in Petrovsk (town), whereas in Uryk (village) I was given only two thousand (rubles). 
Our relatives, to fill up this decrease of the material means, sent us sugar, tea, coffee and various products and clothes." (A. Romanovich-Slavatinskii, 1870:37)

Thus, the noblemen, being aware of the exclusiveness of their status, cared only about the improvement of their own welfare. However, the nobleman was a monopoly landowner, who gave the land to the lifelong users - serfs. Such a situation could be valid only when the land was endowed. However, under conditions of the reduction of land allocation or landlessness of the landowner he "lost" the legal rights to the serfs' work. Nevertheless, the shift in the land relations was not reflected in the change of the behavioral culture of the privileged society strata.

Vanity of the landlords acquired forms of abuse of their high status rights in the legal field and property. In addition, they did not educate their children about the need to work, thereby stopping the creative potential of this society stratum. Favorable attitude to idleness and eternal leisure contributed to deepening crisis in nurturing palette of high aristocratic feelings.

It is worth to note, that the favorable opportunities to become rich, to be accepted by the "higher world" and receive education were used not by all the representatives of the privileged stratum. The reason of this phenomenon can be explained by property and educational differentiation among noblemen and, as the result, the lack of access to the professional knowledge.

The social status of the nobles impelled them to lead a certain lifestyle. They had to dress appropriately, to have a decent accommodation and proper meals, to perform the tasks of public (administrative or military) service, to observe the norms of high society, i.e. to be educated and experienced in arts, including choreography, and to abide by the code of honor.

The culture of the noblemen combined the state service (civilian or military) and entertainments. "The freedom to have entertainments" - Ivan Dolhorukov wrote at the end of the eighteenth century, when in life of the Russian empire, after the abolition of the compulsory service and the establishment of self-sufficient value of private life and even the right to eccentricity, there appeared and solidly entrenched such forms of private entertainment, as amateur theaters. They entertained and, in accordance with the spirit of time, "formed the mind and taste" of the hobbies (for example, natural science classes or collectibles), as well as private "congresses". (Razvliekatielnaia kultura Rassii, 2000: 38) It is also interesting to note, that memoirists related private "lunches, balls, evenings" to the fulfillment of the public demands. (Razvliekatielnaia kultura Rassii, 2000: 39)

"Entering the world" was a guarantee of a stable economic situation of the nobility. Joint leisure helped to establish the necessary personal connections, find a marriage pair and reach self-realization in the society. Therefore, the noblemen used to visit official receptions, lunches, dinners, business meetings, balls, masquerades, fireworks. Since the end of the eighteenth century, fireworks and illuminations became widespread in private use in the capital as well as in the province. The fireworks passion among higher society strata did not disappear even in the first decades of the nineteenth century (Razvliekatielnaia kultura Rassii, 2000: 96-97).

To organize the events, mentioned above, there were used palaces and estates in villages and cities. The balls were organized in provincial Kyiv and in the county cities. "...The ball turned into a crown of society, its highest expression, and the dances - into a cult, the only thing worthy of children of "fun and luxury", and, at the same time, becoming almost the only platform for communication betweenyoung gentlemen and ladies...". For the sake of the ball, the nobles sewed fashionable clothes, invited the most famous musicians and organized lunches, and even reorganized the entire schedule of the day. The balls forced to refuse to sleep at night and to have a rest in the afternoon, to be ready again to go to the dance meeting next day. Thus, the balls turned into a pleasant and difficult duty. (Anna Kolesnykova, 2005: 37) As I. Rozental stated, the annual seasons of dance meetings under the subscription often preceded the 
registration of a noble club in provincial towns. The dancing parties, mentioned above, were like those ones, which were organizing in St. Petersburg at the end of the eighteenth century. They were arranged, for example, for several years in a row - in the winter months, until the fasting - in Kyiv. The statute of one of the capital's clubs served as the basis for the creation of the main document of Kyiv Noble Assembly (subsequently renamed into the Aristocratic Assembly) in 1838, which was approved the next year (Isaak Rozental, 2007: 37). The most popular club entertainments there were the card games, dominoes, lotto and billiards.

As F. Ernst noted, "Warsaw danced, Krakow prayed, Lviv loved, Vilna hunted, and Old Kyiv played in the cards and, therefore, forgot (before the rebirth of the university), that it was appointed by God and by the people to be the capital of all Slavs" (Fedir Ernst, 1997: 54).

The dancing at the balls copied the themes of the most favorite and fashionable operas. Just a short time after a fashionable French or Italian novelty sounded in the theater, there would appear a dance on its topic on the nearest court ball. The style of the dances depended on the particular historical period. At the end of the eighteenth century - in the early nineteenth century it was polonaise, later - waltz, mazurka, French quadrille, and in the early 40's - gallop and polka. (Razvliekatielnaia kultura Rassii, 2000: 197)

The lifestyle, mentioned above, required big expenses, which could be covered from different sources. First, it is worth to note, that the secure financial standing of the upper echelons of the nobility was ensured by hereditary property and - no less important - by political loyalty to the tsarist regime.

The state tried to slow down the decline of the noble land tenure by applying additional financial sanctions. According to the Ministry of the Interior, 6,606,909 serfs, i.e. 62 percent of the total number, were pawned for $398,246,424$ rubles at state credit institutions. By the time the activities of the state credit institutions ended in 1859, the debts had reached 425,503,061 rubles: 44,166 estates and 7,107,184 serfs were in pawn (D. Baturinskiy, 1925: 19).

After the peasant (emancipation) reform of 1861, the landowners also accumulated debt faster, than they paid it off. Their financial position could not be rectified even by the fact, that debts were transferred to the peasants. After the reform, despite the 580,066,883 rubles, received by the landowners in redemption payments, their debt continued to grow. In 1873 - 1886, the landowners' debt rose from 134,300 million to 530,600 million rubles (D. Baturinskiy, 1925: 19).

\section{Conclusions}

Thus, the noble culture of the nineteenth century is characterized by a certain way of life, associated with the recognition of the gentry code of honor, the performance of the state (administrative or military) service, adherence to the rules of the higher society, education, knowledge of the arts and choreography. The noblemen, including the ones from the Kyiv province, adhered to the necessary requirements for clothing, food, housing etc.

The economic and financial conditions for the emergence of the Ukrainian component of the Russian nobility, co-opted from the senior Cossack officers and the Right-Bank gentry, proved sufficient for the increase of the influence of magnateria and its partial parcelizaton as well as for the deprivation of the petty gentry of nobility rights. The attitude of the imperial authorities towards the gentry depended on their loyalty; in case of such loyalty, the gentry were granted financial benefits, even under the conditions of persistent state budget deficits.

Consequently, the vanity of the nobleman (and their families) acquired forms of abuse by their high status rights in the legal field and property. In addition, they did not properly teach their children to love work, thereby stopping the creative potential of this society stratum. 
Favorable attitude towards idleness and eternal leisure contributed to deepening crisis in nurturing palette of high aristocratic feelings.

To continue study the problems, mentioned above, it would be appropriate to explore the family and marriage strategies, confessional transformations and national-ethnic identities of Ukrainian gentry.

\section{References}

Baturinskiy, D. (1925). Agrarnaya politika tsarskogo pravitielstva i Kriestianskii pozemelnyi bank [The Agrarian Policy of the Tsarist Government and the Peasant Land Bank]. Moscow. [in Russian]

Bogolepov, M. I. (1910). Gosudarstvennyi dolg [The State Debt]. Saint Petersburg, [in Russian] Borovoy, S. (1958). Credit i banki Rossii (seredina XVII v. - 1861 g.) [Crediting and Banks in Russia (the mid. 17th -1861$)$. Moscow: Gosfinizdat. [in Russian]

Ernst, Fedir. (1997). Kontakty i kontraktovyi budynok u Kyievi [The Contacts and Contracts Building in Kyiv]. Kyiv: Litopys. [in Ukrainian]

Gindin, I. (1960). Gosudarstvennyi bank i ekonomicheskaya politika tsarskogo pravitelstva (1861 - 1892 gody) [The State Bank and the Economic Policy of the Tsarist Government (1861 -1892)]. Moscow: Gosfinizdat. [in Russian]

Hrytsak, Ya. (2000). Narys istoriyi Ukrainy: formuvannia modernoyi ukrainskoyi natsiyi XIX$X X$ st. [A Survey of Ukrainian History: the Formation of the Modern Ukrainian Nation in the $19^{\text {th }}-20^{\text {th }}$ Centuries]. Kyiv: Heneza. [in Ukrainian]

Hurzhii, I. (1954.) Rozklad feodalno-kriposnytskoyi systemy v silskomu hospodarstvi Ukrainy pershoyi polovyny XIX st. [The Decomposition of the Feudal System and Serfdom in the Agriculture of Ukraine in the First Half of the $19^{\text {th }}$ Century]. Kyiv: The State Publishing House of Political Literature of the UkSSR. [in Ukrainian]

Hurzhiy, O., Orlyk, V. (2012). Seliany Ukrainy ta yikh opodatkuvannia v XVII - seredeni XIX st. [Ukraine's Peasants and Their Taxation in the $17^{\text {th }}-$ mid. $19^{\text {th }}$ Venturies]. Bila Tserkva: Pshonkivskyi. [in Ukrainian]

Khromov, P. (1950). Ekonomicheskoye razvitie Rossii v XIX - XX viekakh (1800 - 1917 gg.) [The Economic Development of Russia in the $19^{\text {th }}-20^{\text {th }}$ centuries $\left.(1800-1917)\right]$. Moscow; The State Publishing House of Political Literature. [in Russian]

Kohut, Z. (1996). Rosiyskyi tsentralizm i ukrainska avtonomiya. Likvidatsia Hetmanshchyny 1760-1830 [Russian Centralism and the Ukrainian Autonomy. The Liquidation of the Hetmanate (1760-1830)]. Kyiv: Osnovy. [in Ukrainian]

Kolesnykova, Anna. (2005). Bal v Rassii XVIII - nachalo XX veka [The ball in Russia. $X$ III $^{\text {th }}$ - the beginning of the XX ${ }^{\text {th }}$ century]. SPB: Azbuka-klassika. [in Russian]

Lavrentieva, Ye. (2007). Povsednevnaya zhizn dvorianstva pushkinskoy pory: Etiket [The Everyday Life of the Pushin-Era Nobility: Etiquette]. Moscow: Molodaia Gvardiia. [in Russian] Lysenko, S., Chernetskyi, Ye. (2006). Legitymovana pravoberezhna shliakhta (kinets XVIII seredyna XIX st.) [The Legitimized Right-Bank Shliakhta (the late $18^{\text {th }}-$ mid-19 ${ }^{\text {th }}$ Centuries)] (Vol.2). Bila Tserkva: Pshonkivskiy. [in Ukrainian]

Migulin, P. (1904). Nasha bankovaya politika (1729 - 1903) [Our Banking Policy (1729 1903)]. Kharkiv: Pechatnoye Delo. [in Russian]

Mordvinov, N. (1829). Rassuzhdenie o polzakh, mogushchikh posledovat ot uchrezhdeniya chastnykh po guberniyam bankov [A Discourse on Benefits that Could Result from Setting Up Private Banks in Provinces]. Saint Petersburg: The Imperial Educational Publishing House. [in Russian] 
Polikarpov V. (1995). Istoria nravov Rassii [The Russia History of the Manners]. Rostovna-Donu: Feniks. [in Russian]

Razvliekatielnaia kultura Rassii XVIII - XIX vv. (2000). [Entertainment Culture of Russia of XVIII-XIX Centuries]. SPB: Pushkinskii dom. [in Russian]

Romanovich-Slavatinskii, A. (1870) Dvorianstvo v Rassii ot nachala XVIII vieka do otmieny krieposnogo prava [The Nobility in Russia from the Beginning of the XVIII Century Until the Abolition of Serfdom]. SPB.: Tipografia Ministerstva vnutriennikh diel. [in Russian]

Rozental, Isaak. (2007). I vot obshchiestviennoie mnieniie! Kluby $v$ istorii rassiiskoi obshchiestviennosti. Koniets XVIII - nachalo XXv. [And This is the Public Opinion! Clubs in the History of the Russian Public. The End of the XVIII ${ }^{\text {th }}$ - the Beginning of the XX ${ }^{\text {th }}$ Century]. M.: Novyi khronohraf. [in Russian]

Smelkov, V. M. (1904). Dvorianskiy melkiy bankovyi kredit [Small Bank Loans for the Nobility]. Saint Petersburg, Russia: The Krovitskiy Publishing House. [in Russian]

Stepa, P. (2010). Ukrainets i moskvyn. Dvi protylezhnosti [The Ukrainian and the Russian. Two opposites]. Drohobych, Vidrodzhennia. [in Ukrainian]

The Central State Historical Archives of Ukraine in Kyiv (CSHAK) (Fund 486, description 9, file 2, 495p.). [in Russian]

The Central State Historical Archives of Ukraine in Kyiv (CSHAK) (Fund 491, description 45, file 14, 25p.). [in Russian]

The Central State Historical Archives of Ukraine in Kyiv (CSHAK) (Fund 442, description 79, file 19, 25p.). [in Russian]

Vandych, P. (2004). Tsina svobody. Istoriya Tsentralno-Skhidnoyi Yevropy vid Seredniovichchia do siohodennia. [The Price of the Freedom. The History of Central and Eastern Europe from the Middle Ages Till Nowadays]. Kyiv: Krytyka. [in Ukrainian]

Yakovenko, N. (2005). Narys istoriyi seredniovichnoyi ta ranniomodernovoyi Ukrainy [A Survey of the History of Medieval and Early Modern Ukraine]. Kyiv: Krytyka. [in Ukrainian] 